\title{
Integration of video lessons to Grade-9 science learners amidst COVID-19 pandemic
}

\author{
Bullo, Marnel $\bowtie$ \\ Cataingan National High School, Philippines (marnel.bullo@deped.gov.ph)
}

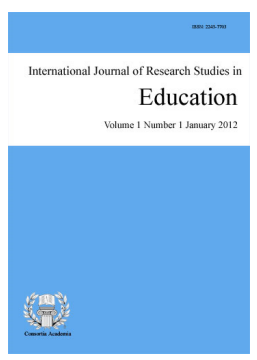

Accepted: 10 June 2021

ISSN: 2243-7703 Online ISSN: 2243-7711

OPEN ACCESS

\section{Abstract}

One of the most disrupted arrays of activities worldwide was the education sector. The overall landscape of learning has changed significantly because of the COVID-19 pandemic. This action research focused on the integration of video lessons to grade-9 science learners amidst the COVID-19 pandemic. The study was a descriptive-experimental method about video lessons integration to grade-9 science learners with 30 student-learners of Cataingan National High School of Poblacion, Cataingan, Masbate as research subjects. The research question was based on the performance of the selected respondents with regards to before and after the application of the video lessons approach. The main purpose was to find the degree of significant difference between the performance of the student-respondents before and after attending the integration of video lessons. The T-test was utilized to determine the statistical results. In the final findings, the researcher concluded that for all weeks of pre-tests and post-tests, the null hypothesis was rejected, which tells us that the difference between their means was statistically significant. Therefore, the science video lessons were significantly effective than modular learning. Once these two are combined, would also prove as a very good combination.

Keywords: education, science, video lessons, Grade 9 learners, COVID-19 pandemic, descriptive design, Philippines 


\section{Integration of video lessons to Grade-9 science learners amidst COVID-19 pandemic}

\section{Introduction}

The coronavirus (COVID-19) pandemic has become a global health crisis and an unprecedented emergency that has affected all global industries, including education (see Ayittey et al., 2020). With the widespread implementation of social distancing and self-isolation policies, it is not feasible for educators and students to attend lessons or assessments as they have previously. The COVID19 pandemic has disrupted our long-standing educational practices and precipitated an urgent need for many institutions to implement alternative educational strategies. However, as novel as this situation is to all, this sudden shift to E-Learning faces many controversies including how poor or good is the capacity of the country in this transition. Filipino people are said to be resilient, but is this enough? The primary problem lies in the economic and social situations of Filipino families which carry the inquiry to E-Learning capacity to meet the challenges of the moment at hand (Pamaran, 2020).

Education must design the future of tomorrow so the students may learn to work with others. The educational design we want to have in the future remains a question amidst the pandemic situation. While logistically sound, taking too many online courses or having poor online instruction can be harmful to a student's future. One of the most glaring issues with online education is the lack of interpersonal communication. A big disadvantage to middle and high school students is the lack of one-on-one support (Hussain, 2017). Video lessons can bridge geographic regions between learning requirements and delivery. On the other hand, e-learning is self-paced, independent of geographic location and time. Then distance learning is online self-paced learning with instructor facilitation, independent of geographic location and time (Akyol \& Garrison, 2011).

The values that were measured in video lessons were about the behaviors of the students regarding the course, the relationship between gender and their success, and their ability to use the knowledge that they had learned. The results showed that the electronic curriculum which is used affects students' long-term learning success affirmatively and also, the students who are more responsible for the course had succeeded with higher grades in this blended learning environment. In the other words, blended learning is the third generation of distance education systems that maximize the best advantage of face-to-face learning and multiple technologies after correspondence education via mail and radio and distance education through a single technology such as computer-based and web-based learning as cited. Some researchers used a virtual teaching environment to develop or teach to examine the effects of a blended learning environment on the students and they showed that if students had enough time and computer access, blended learning would be beneficial. worked on the effectiveness of integrating into individualized English listening and speaking instruction by using a virtual learning environment.

Researchers found that attending participants in the treatment improved their listening and speaking as well as open-mindedness. Besides, they can equip themselves with the critical thinking skills that they need to deal with unexpected communication pitfalls in practice (Brown \& Green, 2016). The writer found out that most of the students are not- participative in listening seriously during lectures and further plan to study about the problems encountered by most students in Grade 9. This argues that the continuing decline in numbers of serious learners at the point of choice requires a research focus on students' attitudes to the nature of the problem to be understood. Starting from a consideration of what is meant by engagement to video lessons. It considers the problems inherent to their personality, what is known about students' attitudes towards learning, and the many factors of influence such as gender, teachers, culture, and other variables (Badia \& Colosimo, 2013).

The literature itself points to the crucial importance of the quality of teaching. Given the importance of the latter, we argue that there is a greater need for research to identify those aspects of teaching to video lesson approach that will make school engaging for students. In particular, a growing body of research on 
learning-remediation programs offers important pointers to the kind of classroom environment and activities that might raise students' interest in developing their learning abilities and a focus for future research (Goodwin, J. 2017). Modular learning has been encouraged or pushed for distribution to learners in the present pandemic situation. There is a comparison as to which is better, modules or video lessons. There is a need for the new normal to introduce video lessons. Although videos are not so interactive, sure learners will be more interested and feel it as more interesting and enjoyable to engage in. That is why the purpose of this action research is focused on this video lesson application and integration in the new normal. This study focused on the descriptive-experimental method of research about the integration of video lessons to grade-9 science learners amidst the covid-19 pandemic. This was for selected learners on their perceptions and reactions to this video lesson teaching.

\subsection{Research question}

The main objective of the study is to specifically attempt to answer the following question:

$>\quad$ Is there a significant difference between the performance of the learner-respondents in the control group using printed modules with that of the experimental group using video lessons to grade-9 science learners amidst the covid-19 pandemic?

\subsection{Null hypothesis}

There is no significant difference between the performance of the student-respondents before and after attending the integration of video lessons to grade- 9 science learners amidst the covid-19 pandemic.

\section{Methodology}

The administration of the Pretest was the first part of the study. This was given to the control group and experimental group of learners-respondents before the intervention of modules and video lessons weekly. The 30 learners-respondents from a control group and the other 30 learners-respondents from the experimental group were given the 5 items pretest weekly lessons based on most essential learning competencies. Then modules and video lessons were given to learners-respondents right after the conduct of the pre-test with parents' guidance. The next part was the administration of 10 post-test given to learners-respondents. The teacher-researcher collected the responses in both pre-test and post-test and the last part of the study was data checking, encoding, analysis, and interpretation of data.

\subsection{Research design}

This action research used the descriptive-experimental method from two-groups pretest-posttest design. Donald Kirkpatrick's Four Level Evaluation Model (1959); review and contextual material Alan Chapman (1995-2014) established a participant reactions method and such was applied by the researcher to the virtual teaching-learning evaluation of the approach as shown in a diagram shown below:

This evaluation is going to provide the following: 1) reaction evaluation to measure learners (trainers) pre-knowledge and how they thought and felt about the virtual teaching-learning experience, 2) learning evaluation which is to measure the increase of knowledge before and during virtual teaching, to provide corrective actions at the end, 3) behavior evaluation which is to measure the extent of applied learning back on the program implementation of knowledge, and 4) result evaluation which investigates the effects on the virtual teaching approach resulting from the learners' performance, and try to assess

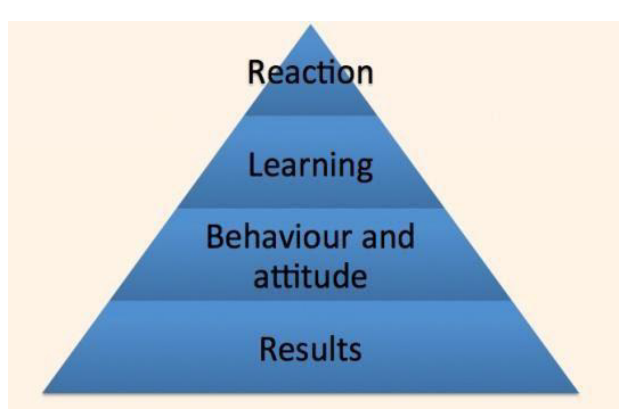
and validate the impact of the approach using the extended 
Bullo, M.

Kirkpatrick's evaluation model.

\subsection{Respondents of the study}

The researcher limited the study to the selected Grade-9 learners under the classified respondents. The respondents of this study were taken from grade 9 learners of Cataingan National High School, Poblacion, Cataingan, Masbate. There were a total of 60 learners from two sections from regular classes involved. The first 30 learners were from the grade 9 section Gray acted as the control group of the study. While the other 30 learners were from the grade 9 section Cream acted as the experimental group of the study.

\subsection{Research instruments}

The teacher-researcher used the video lessons as instruments in conducting this study. The video lessons are created, developed, and validated by selected science teachers and experts in School Divisions of Masbate Province. The researcher developed questionnaires for pre-test and post-test anchored on most essential learning competencies lessons and was assessed and validated by science validators.

\subsection{Statistical treatment}

The statistical tools used were mean percentage score and weighted mean for analysis and interpretation of data. T-test for paired two samples was used if there is a significant difference in pre-test and post-test mean gain by learner-respondents of the two groups. Pearson Correlations or Pearson $\mathrm{R}$ was used to determine the significant level of the performance from the control group and experimental group.

\section{Results and discussion}

Based on the gathered and analyzed data, the researcher found out the following:

\subsection{T-test: Paired two sample analysis of experimental group (video lessons)}

\section{Table 1}

T-test: Paired two sample for means in week 1 \& 2 grade 9-section cream (experimental group)

\begin{tabular}{lcc}
\hline & Pretest & Posttest \\
\hline Mean & 1.2 & 7.166667 \\
Variance & 0.717241379 & 3.109195 \\
Observations & 30 & 30 \\
Pearson Correlation & 0.138546824 & \\
Hypothesized Mean Difference & 0 & \\
Df & 29 & \\
t Stat & -17.69077794 & \\
p(T<=t) one-tail & $2.21811 \mathrm{E}-17$ & \\
t Critical one-tail & 1.699127027 & \\
$\mathrm{p}(\mathrm{T}<=\mathrm{t})$ two-tail & $4.43623 \mathrm{E}-17$ & \\
$\mathrm{t}$ Critical two-tail & 2.045229642 & \\
\hline
\end{tabular}

In this table for weeks 1 and 2, the coverage of the lesson was about: explain how the respiratory and circulatory systems work together to transport nutrients, gases and other molecules to and from the different parts of the body and infer how one's lifestyle can affect. The practical significance or value can be best seen as gained across the percentage score range from lower in pretest and highest in posttest as indicated in week 1 and 2 , the $p$-value was $4.43623 \mathrm{E}-17$, which was less than the value of the standard significance level of 0.05 . We rejected the null hypothesis and concluded that the difference between their means was statistically significant which means that the integration of video lessons as intervention was effective. 
Integration of video lessons to Grade-9 science learners amidst COVID-19 pandemic

Table 2

T-test: Paired two sample for means in week $3 \& 4$ grade 9-section cream (experimental group)

\begin{tabular}{lcc}
\hline & Pretest & Posttest \\
\hline Mean & 2.866666667 & 7.9333 \\
Variance & 0.809195402 & 3.1678 \\
Observations & 30 & 30 \\
Pearson Correlation & 0.532694201 & \\
Hypothesized Mean Difference & 0 & \\
Df & 29 & \\
t Stat & -18.4140415 & \\
p(T<=t) one-tail & $7.6078 \mathrm{E}-18$ & \\
t Critical one-tail & 1.699127027 & \\
p(T<=t) two-tail & $1.52156 \mathrm{E}-17$ & \\
t Critical two-tail & 2.045229642 & \\
\hline
\end{tabular}

In this table for weeks 3 and 4, the coverage of the lesson was about: the different patterns of non-Mendelian inheritance. For week 3 and 4 , the $p$-value was $1.52156 \mathrm{E}-17$, which was less than the value of the standard significance level of 0.05 . We rejected the null hypothesis and concluded that the difference between their means was statistically significant which means that the integration of video lessons as intervention was effective.

Table 3

T-test: Paired two sample for means in week 5 grade 9-section cream (experimental group)

\begin{tabular}{lcc}
\hline & Pretest & Posttest \\
\hline Mean & 2.666666667 & 7.4 \\
Variance & 0.781609195 & 3.0069 \\
Observations & 30 & 30 \\
Pearson Correlation & 0.269916339 & \\
Hypothesized Mean Difference & 0 & \\
Df & 29 & \\
t Stat & -15.0665707 & \\
p(T<=t) one-tail & $1.49815 \mathrm{E}-15$ & \\
t Critical one-tail & 1.699127027 & \\
$\mathrm{p}(\mathrm{T}<=t)$ two-tail & $2.9963 \mathrm{E}-15$ & \\
$\mathrm{t}$ Critical two-tail & 2.045229642 & \\
\hline
\end{tabular}

As shown in this table for week 5, the coverage of the lesson was about: the species extinction to the failure of the populations of organisms to adapt to abrupt changes in the environment. For week 5, the $p$-value was $2.9963 \mathrm{E}-15$, which was less than the value of the standard significance level of 0.05 . We rejected the null hypothesis and concluded that the difference between their means was statistically significant which means that the integration of video lessons as intervention was effective.

Table 4

T-test: Paired two sample for means in week 6 \& 7 grade 9-section cream (experimental group)

\begin{tabular}{lcc}
\hline & Pretest & Posttest \\
\hline Mean & 2.466666667 & 8.1333 \\
Variance & 1.016091954 & 4.1885 \\
Observations & 30 & 30 \\
Pearson Correlation & 0.403388255 & \\
Hypothesized Mean Difference & 0 & \\
Df & 29 & \\
t Stat & -16.4957688 & \\
p $(T<=t)$ one-tail & $1.41164 \mathrm{E}-16$ & \\
t Critical one-tail & 1.699127027 & \\
$\mathrm{p}(\mathrm{T}<=t)$ two-tail & $2.82328 \mathrm{E}-16$ & \\
$\mathrm{t}$ Critical two-tail & 2.045229642 & \\
\hline
\end{tabular}

As depicted in this table for weeks 6 and 7, the coverage of the lesson was about: differentiate basic features and importance of photosynthesis and respiration. For weeks 6 and 7, the $p$-values were 2.82328E-16, which was less than the value of the standard significance level of 0.05 . We rejected the null hypothesis and concluded that the 
Bullo, M.

difference between their means was statistically significant which means that the integration of video lessons as intervention was effective.

3.2 T-test: Paired two sample analysis of control group (modular group)

\section{Table 1}

T-test: Paired two sample for means in week $1 \& 2$ grade 9-section gray (control group)

\begin{tabular}{lcc}
\hline & Pretest & Posttest \\
\hline Mean & 1.1 & 3.6667 \\
Variance & 0.782758621 & 2.4368 \\
Observations & 30 & 30 \\
Pearson Correlation & $-4.43517 \mathrm{E}-17$ & \\
Hypothesized Mean Difference & 0 & \\
$\mathrm{df}$ & 29 & \\
$\mathrm{t}$ Stat & -7.834894803 & \\
$\mathrm{p}(\mathrm{T}<=\mathrm{t})$ one-tail & $6.09423 \mathrm{E}-09$ & \\
$\mathrm{t}$ Critical one-tail & 1.699127027 & \\
$\mathrm{p}(\mathrm{T}<=\mathrm{t})$ two-tail & $1.21885 \mathrm{E}-08$ & \\
$\mathrm{t}$ Critical two-tail & 2.045229642 & \\
\hline
\end{tabular}

For weeks 1 and 2, the $p$-value was $1.21885 \mathrm{E}-08$, which was less than the value of the standard significance level of 0.05 . We rejected the null hypothesis and concluded that the difference between the means of pre- and post-test scores was statistically significant which means that the modular intervention was effective.

\section{Table 2}

T-test: Paired two sample for means in week 3 \& 4 grade 9-section gray (control group)

\begin{tabular}{lcc}
\hline & Pretest & Posttest \\
\hline Mean & 1.633333333 & 2 \\
Variance & 0.998850575 & 1.3103 \\
Observations & 30 & 30 \\
Pearson Correlation & 0.060282178 & \\
Hypothesized Mean Difference & 0 & \\
Df & 29 & \\
t Stat & -1.36293676 & \\
p(T<=t) one-tail & 0.091696242 & \\
t Critical one-tail & 1.699127027 & \\
p(T<=t) two-tail & 0.183392483 & \\
t Critical two-tail & 2.045229642 & \\
\hline
\end{tabular}

For weeks 3 and 4, the $p$-value was 0.183392483 , which was greater than the value of the standard significance level of 0.05 . We accepted the null hypothesis and concluded that the difference between the means of pre- and post-test scores was not statistically significant which means that the modular intervention was not effective.

\section{Table 3}

T-Test: Paired two sample for means in week 5 grade 9-section gray (control group)

\begin{tabular}{lcc}
\hline & Pretest & Posttest \\
\hline Mean & 1.9 & 4 \\
Variance & 0.644827586 & 2.3448 \\
Observations & 30 & 30 \\
Pearson Correlation & 0.168258104 & \\
Hypothesized Mean Difference & 0 & \\
Df & 29 & \\
t Stat & -7.166690016 & \\
p $(T<=t)$ one-tail & $3.4447 \mathrm{E}-08$ & \\
t Critical one-tail & 1.699127027 & \\
p $(T<=t)$ two-tail & $6.88941 \mathrm{E}-08$ & \\
t Critical two-tail & 2.045229642 & \\
\hline
\end{tabular}

72 Consortia Academia Publishing (A partner of Network of Professional Researchers and Educators) 
For week 5, the $p$-value was 6.88941E-08, which was less than the value of the standard significance level of 0.05 . We rejected the null hypothesis and concluded that the difference between the means of pre- and post-test scores was statistically significant which means that the modular intervention was effective.

\section{Table 4}

T-Test: Paired two sample for means in week 6 \& 7 grade 9-section gray (control group)

\begin{tabular}{lll}
\hline & Pretest & Posttest \\
\hline Mean & 1.433333333 & 1.733333333 \\
Variance & 0.874712644 & 1.71954023 \\
Observations & 30 & 30 \\
Pearson Correlation & 0.041237711 & \\
Hypothesized Mean Difference & 0 & \\
Df & 29 & \\
t Stat & -1.040666878 & \\
P(T<=t) one-tail & 0.153314499 & \\
t Critical one-tail & 1.699127027 & \\
P(T<=t) two-tail & 0.306628997 & \\
t Critical two-tail & 2.045229642 & \\
\hline
\end{tabular}

As shown in table no. 3 for weeks 6 and 7, the $p$-value was 0.306628997 , which was greater than the value of the standard significance level of 0.05 . We accepted the null hypothesis and concluded that the difference between the means of pre- and post-test scores was not statistically significant which means that the modular intervention was not effective.

\subsection{Pearson $R$ correlation analysis}

Table 1

Pearson $R$ correlation analysis of modular and video lessons interventions

\begin{tabular}{cccccc}
\hline \multirow{2}{*}{ Interventions } & \multirow{2}{*}{$\begin{array}{c}\text { Pear \& } \\
\text { Section }\end{array}$} & $\begin{array}{c}\text { Week } \\
\text { 1 and 2 }\end{array}$ & $\begin{array}{c}\text { Week } \\
3 \text { and } 4\end{array}$ & Week & Week \\
& 9-Cream & 0.138546824 & 0.532694201 & 0.269916339 & 0.403388255 \\
\hline $\begin{array}{c}\text { Video } \\
\text { Messons }\end{array}$ & 9-Gray & $-4.43517 \mathrm{E}-17$ & 0.060282178 & 0.168258104 & 0.041237711 \\
\hline
\end{tabular}

Table 1 shown in comparing the two interventions, the integration of Video lessons to grade-9 section Cream and grade 9 section Gray who utilized the modular approach. The writer utilized the Pearson Correlation from the t-test analysis to measure the strength and direction of a linear relationship between two variables. The researcher decided to do so since both interventions were effective for some weekly lessons though there were weeks that modular was not effective after analyzing their respective pre-test and post-test scores. However, Pearson Correlation suggested that the video lessons integration to grade 9 section Cream have a more positive correlation, which ranges from 0.138546824 to 0.532694201 , than modular intervention of grade 9 section gray, which ranges from $-4.43517 \mathrm{E}-17$ to 0.168258104 .

\section{Conclusion}

Based on the data presented, the researcher therefore concluded, that for all weeks of pre-tests and post-tests, null hypothesis was rejected on the utilization and intervention of video lessons which tells us that the difference between their means was statistically significant and partially accepted the null hypothesis on modular approach which tells us that the difference between their means was not statistically significant. Video lessons were more effective in all learning competencies though modular approaches in some areas were also effective to students learning during this difficult time. Video lessons helped students better understand and comprehend the lessons even without the help of a teacher. Thus, given this information and data the combination of the video lessons 
Bullo, M.

and modular approaches in teaching will result in an effective learning.

\subsection{Recommendations}

The following are recommended based on the findings and conclusion of the study:

$>$ Conduct research on the perceived effect of learners after using the video lessons.

$>\quad$ Conduct research on the acceptability and applicability of video lessons for all learners across learning areas.

$>\quad$ It is highly recommended that video lessons be integrated with modular learning to grade-9 science learners amidst COVID-19 19 pandemic and was effective.

Acknowledgements: The author expressed his gratitude Schools Division Superintendent of DepEd Masbate Province Nene Roal-Merioles, CID Chief Dorothy L. Daniel, EPS I in Science Dr. Manuel F. Teodoro, School Principal IV Engr. Jesus P. Dela Pena, Science Department Head Teacher III Madilyn B. Povadora, Science Writers/Demo Science Teachers, Reviewers and Validators of SDO Masbate Province.

\section{References}

Akyol, Z., \& Garrison, D. R. (2011). Understanding cognitive presence in an online and blended community of inquiry: Assessing outcomes and processes for deep approaches to learning. British Journal of Educational Technology, 42(2), 233-250. https://doi.org/10.1111/j.1467-8535.2009.01029.x

Albrecht, B. (2006). Enriching student experience through hybrid learning (Research Bulletin, 2006, no. 12). Washington, DC: Educause Center for Applied Research.

Badia, G., \& Colosimo, A. L. (2013). Best practices for engaging users in a web conferencing environment. ASEE Annual Conference and Exposition, Conference Proceedings, Atlanta, Georgia.

Brown, A., \& Green, T. D. (2016). The essentials of instructional design: Connecting fundamental principles with process and practice. New York: Routledge. https://doi.org/10.4324/9781315757438

DepEd Ten Point Basic Education Agenda. (2010) Retrieved from https://www.teacherph.com/10-point-basic-education-agenda/

Goodwin, J. (2017). Students' perceptions of teaching and social presence: A comparative analysis of face-to-face and online learning environments. International Journal of Web-Based Learning and Teaching Technologies, 10(1), 27-44. https://doi.org/10.4018/ijwltt.2015010103

Hussain, F. (2017). Teaching in primary schools in China and India: Contexts of learning. Asia Pacific Journal of Education. https://doi.org/10.1080/02188791.2017.1274488

Lechner, U., \& Schmid, B. (2000). Community and media: Towards a reconstruction of communities on media. Proceedings of the 33rd International Conference on Systems Sciences, Hawaii. https://doi.org/10.1109/HICSS.2000.926817

Link to Graphs of Reading, Math, Science Proficiency, Grades K-12.

Means, B., Toyama, Y., Murphy, R., \& Baki, M. (2013). The effectiveness of online and blended learning: A meta-analysis of empirical literature. Teachers College Record, 115,1-47.

Muilenburg, L. Y., \& Berge, Z. L. (2016). Digital badges in education: Trends, issues, and cases. New York: Routledge, Taylor \& Francis. https://doi.org/10.4324/9781315718569

Pamaran, M. D. (2020). Education post-Covid-19 will be largely virtual-but is the Philippines ready? Retrieved from https://news.abs-cbn.com/ancx/culture/spotlight/04/23/20/education-post-covid-19-will-be-largely-virtu albut-is-the-philippines-ready

Picciano, A., Dziuban, C., \& Graham, C. (Eds.) (2014). Blended learning: Research perspectives (Vol. 2). New

74 Consortia Academia Publishing (A partner of Network of Professional Researchers and Educators) 
York: Routledge. https://doi.org/10.4324/9781315880310

Roblyer, M. D. (2006). Integrating educational technology into teaching (4th ed.). Upper Saddle River, NJ: Pearson Education, Merrill.

Umali, D. (2014). Designing LibGuides as instructional tools for critical thinking and effective online learning. Journal of Library \& Information Services in Distance Learning, 8(3-4), 107-117. https://doi.org/10.1080/1533290X.2014.944423 
Bullo, M.

76 Consortia Academia Publishing (A partner of Network of Professional Researchers and Educators) 